\title{
STUDY OF THE FLAVONOIDS AND SECONDARY METABOLITES OF THE ARGAN TREE (Argania spinosa L.)
}

\author{
Miloudi HILALI ${ }^{\star 凶}$, Hanae El MONFALOUTI and Badr Eddine KARTAH \\ Laboratory of Plant Chemistry and Organic and Bioorganic Synthesis, Faculty of Science, University Mohamed-V, Av. Ibn Battouta, BP 1014 Agdal- \\ Rabat, Morocco
}

\author{
Email: hilali400@yahoo.com ; Quriz: 0000-0003-2062-2969 \\ Supporting Information
}

\begin{abstract}
The separation and identification of the main phenolic compounds present in the co-product of the Argan tree (Argania spinosa) were carried out using high performance liquid chromatography techniques coupled with mass spectrometry (LC-ESI-MS/MS).The study was based on the retention times of the peaks of the phenolic compounds in samples and was compared to those of the controls (reference compounds) and supplemented by an analysis of the fragmentations of the molecules by mass spectrometry. Phenolic compounds in the pulp of the Argan namely such as catechin (2.8\%), epicatechin (14.7\%), procyanidin $(2.7 \%)$, quercetin (1.6\%), luteolin (0.2\%) and naringenin $(0.07 \%)$ were found. Phenolic acid is consisted of gallic acid (5\%) and protocatechuic acid $(21.1 \%)$. These compounds are more dominant than flavonoids. The flavonoids-0rhamnoglucosides the most dominant compounds is isorhoifoline $(7.2 \%)$ and hesperidin $(4.5 \%)$ against rutin $(0.1 \%)$ and rhamnetin-0-rutinoside $(0.5 \%)$ are less dominant. The main compounds are the hyperoside $(13.4 \%)$ and isoquercetin (10\%). On the other hand, naringenin-7-0-glucoside constituted the most minority compound of this type of flavonoid in the pulp of the fruit of the Argan tree (the percentage of naringenin-7-0-glucoside and quercetin-3-0-arabinose is $15.3 \%$ ). There are other phenolic compounds in the pulp of the Argan namely such as catechin $(2.8 \%)$, epicatechin (14.7\%), procyanidin $(2.7 \%)$, quercetin $(1.6 \%)$, luteolin $(0.2 \%)$ and naringenin (0.07\%). The main flavonoids found in the leaves of the Argan tree are Quercetin (21.73\%), Myricetin (54.34\%), Hyperoside (8.69\%), and also Myricetin-3-Ogalactoside (9.78\%). Argan cake is rich in flavonoids. Among these, epicatechin $(110 \mathrm{mg} / \mathrm{kg})$, catechin $(11 \mathrm{mg} / \mathrm{kg})$, protocatechic acid $(15.2 \mathrm{mg} / \mathrm{kg})$, vanillic acid $(16.3 \mathrm{mg} / \mathrm{kg})$ and 4-hydroxybenzyl alcohol (8.6 mg/kg) are higher in Argan cake. Argan oil is richer in tocopherol (597 to 775 $\mathrm{mg} / \mathrm{kg})$, Argan oil is rich in gamma tocopherol $(631 \mathrm{mg} / \mathrm{kg})$, and that make Argan valuable nutraceutical. The study of the secondary metabolites and especially the flavonoids of the Argan tree was undertaken with the aim of identifying new metabolites making it possible to increase the industrial than commercial value of the Argan tree.
\end{abstract}

Keywords: Argan tree, Biological activity, Flavonoids, Metabolism, Phenolic acids.

\section{INTRODUCTION}

The Argan tree (Argania spinose L. Skeels) is used by the local populations : the wood and the woody shell of the fruit for heating. The almond of the fruit is used in the production of Argan oil. The foliage and the pulp of the fruit and also the oil cake (residue from the production of Argan oil) are designed for animal nutrition (Pumareda et al., 2006). The study of the chemical composition of Argan derivatives was undertaken with the aim of identifying new metabolites allowing increasing the industrial than commercial value of the Argan tree. Secondary metabolites are compounds naturally biosynthesized by plants but which do not directly participate in plant metabolism. Many secondary metabolites have therapeutic properties and are (or have been) used in human medicine (Gitton-Ripoll, 2009; Khallouki et al., 2017). A systematic study of the secondary metabolites of the Argan tree has been developed since the 1990s in order to see to what extent it is possible to increase the economic value of the Argan grove and hence promote its extension in the long term. The results of this study have revealed a wide variety of secondary metabolites within the different parts of the Argan tree. Besides molecules frequently encountered in higher plants (triterpenes, sterols, flavonoids, etc.), molecules of original structure and belonging to the group of flavonoids have been isolated. Multiple flavonoids, also extracted from plant species other than Argan (El Kabouss et al., 2001; Zhar et al., 2016; Falode et al., 2019), have therapeutic properties which are sufficiently encouraging to warrant further investigation (Guillaume et al., 2005). Some other flavonoids seem to be involved in phytoprotective phenomena (Jiang et al., 2020). Applications in the food or cosmetology fields are also being studied. All this clearly indicates that this chemical family of secondary metabolites has interesting potential in many fields. As a result, the analysis of several parts of the Argan tree (wood, oil cake, shell and fruit pulp) was carried out and many flavonoids of different and often original structures could be isolated and then identified, and the properties of certain d 'have been evaluated (Safer, 2018; Hilali et al., 2020). This study briefly describes the flavonoids of the Argan tree. 


\section{MATERIALS AND METHODS}

\section{Plant material}

The fruits of the Argan tree and their leaves are harvested in the village of Tidzi province of Essaouira, The collected samples are dried in the open air then pulped, crushed and finally reduced, separately, in fine powder (Bellefontaine et al., 2011).

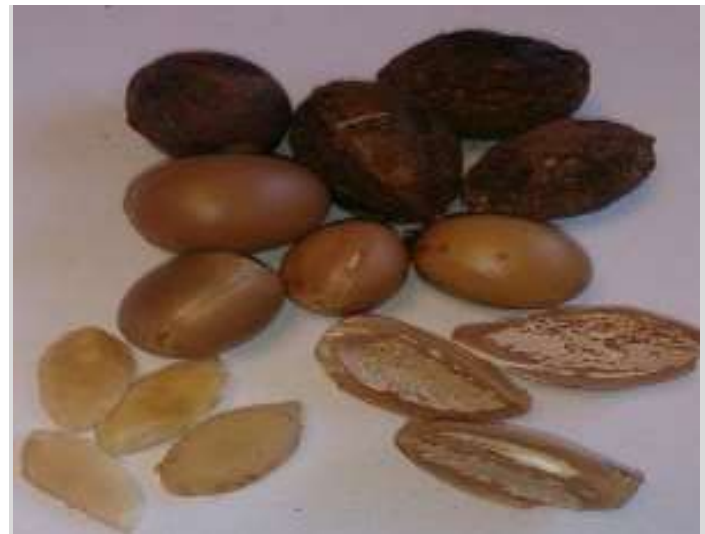

Figure 1 - Different parts of the Argan fruit

\section{Identification of phenolic compounds}

The separation and characterization of the main phenolic compounds present in the Argan fruit pulp were carried out using high performance liquid chromatography techniques coupled with mass spectrometry (LC-ESI-MS/MS). This method already applied on other plants (cocoa, lepechinia graveolens) (Sánchez-Rabaneda et al., 2003) is important for the study of polyphenols. It makes it possible to determine the molecular weight and to give certain structural information of the molecules (Adlouni, 2010). In our study, we based ourselves on the retention time of the peaks of the phenolic compounds in our sample and compared to those of the control peaks of the reference compounds.

\section{RESULTS AND DISCUSSION}

\section{Phenolic compounds of the pulp of the Argan fruit}

The study of the phenolic composition of the pulp of Argan fruit has identified 16 phenolic compounds (Table 1). This study was approached as a biochemical approach to establish a polyphenolic identity card and allows highlighting a fairly significant structural diversity encompassing four main groups of phenolic compounds (El Kabouss et al., 2001; Charrouf et al., 2007). Phenolic acids consisting of gallic acid (5\%) and protocatechuic acid (21.1\%). These compounds are more dominant than flavonoids. In our study we did not find $p$-hydroxybenzoic acid among the phenolic acids in Argan pulp. The flavonoids-0-rhamnoglucosides the most dominant compounds is isorhoifoline $(7.2 \%)$ and hesperidin (4.5\%) against rutin $(0.1 \%)$ and rhamnetin-0-rutinoside $(0.5 \%)$ are less dominant. Flavonoids-0-glycosides: The main compounds are the hyperoside (13.4\%) and isoquercetin (10\%). On the other hand, naringenin-7-0-glucoside constituted the most minority compound of this type of flavonoid in the pulp of the fruit of the Argan tree (the percentage of naringenin-7-0-glucoside and quercetin-3-0-arabinose is 15.3\%), (compounds 11 and 12). There are other phenolic compounds in the pulp of the Argan namely such as catechin (2.8\%), epicatechin (14.7\%), procyanidin (2.7\%), quercetin (1.6\%), luteolin (0.2\%) and naringenin $(0.07 \%)$. It is noted that epicatechin was the most affordable compound in the pulp of the Argan fruit after Protocatechuic acid (21.1\%). The pulp of Argan fruit has been found to be rich in epicatechin and other catechic derivatives whose natural antioxidant power is important according to numerous studies (Ba et al., 2010). However, such combinations of natural phenolic compounds could be used for better preservation of Argan oil.

\section{Phenolic compounds of Argan leaves}

The study of the extracts of the leaves of the Argan tree by chromatography shows a higher content of flavonoids in the leaves of the Argan tree (Table 2) which are flavonic molecules including (Myricetin 3-0-galactoside, the hyperoside, quercitrine and myricitrine). The main flavonoids found in the leaves of the Argan are Quercetin, Myricetin and their glycosides (Quercetin, Myricetrine, Hyperoside, and Myricetin 3-0-galactoside) (Tahrouch et al., 1998). The derivatives of these aglycones represent $16.5 \%$ of the total flavonoids. The flavonoid extract of the leaves has a very interesting antiradical and antioxidant activity. It is currently marketed as a protective cosmetic active ingredient for extracellular macromolecules in the skin such as collagen, glycoproteins, etc. (Charrouf et al., 2009).

\section{Phenolic compounds in Argan oil}

The proportion of phenols in Argan oil is low but their impact on its biological properties is very important. These are caffeic acids, 4-hydroxybenzoic, vanillic, syringic, ferrulic 4-o-glycosylated, oleuropein, 3-hydroxypyridine (3-Pyridinol), 6- 
methyl-3-hydroxypyridine and catechol, resorcinol, vanillyl alcohol, tyrosol, 4 hydroxy-3-methoxyphenethyl, epicatechin and catechin (Guillaume et al., 2005).

\section{Table 1 - Phenolic compounds of the pulp of the Argan fruit}

\begin{tabular}{|c|c|c|c|c|c|c|c|}
\hline $\mathbf{N}^{\circ}$ & Compounds (\%) & $\begin{array}{l}\text { Retention } \\
\text { time (min) }\end{array}$ & {$[\mathrm{M}-\mathrm{H}]$} & Fragments & $\begin{array}{c}\text { MS/MS } \\
\text { (Experimental } \\
\text { method) Neutral } \\
\text { loss scan }\end{array}$ & $\begin{array}{l}\text { MS/MS (Experimental } \\
\text { method) Precursor } \\
\text { scan }\end{array}$ & $\begin{array}{c}\text { MS/MS } \\
\text { (Experimental } \\
\text { method) } \\
\text { Production }\end{array}$ \\
\hline 1 & Gallic acid (5.0) & 0.82 & 169 & 125 & - & - & - \\
\hline 2 & Protocatechuic acid (21.8) & 1.44 & 153 & 109 & - & - & - \\
\hline 3 & Catechine (2.8) & 4.06 & 289 & - & - & 289 & 245 \\
\hline 4 & Isorhoifoline (7.2) & 7.13 & 577 & - & - & - & - \\
\hline 5 & Epicatechin (14.7) & 7.65 & 289 & - & - & 289 & 245 \\
\hline 6 & Procyanidin (2.7) & 7.67 & 579 & - & - & 579 & 289,245 \\
\hline 7 & Rutin (0.1) & 10.87 & 609 & - & 308 & 609 & 301 \\
\hline 8 & Hesperidin (4.5) & 11.19 & 609 & 463.301 & 308 & 609 & 301 \\
\hline 9 & Hyperosid (13.4) & 11.46 & 463 & - & 162 & 463 & 301 \\
\hline 10 & Isoquercitrine (10) & 11.70 & 463 & - & 162 & 463 & 301 \\
\hline 11 & Quercetine-o-pentose & 12.33 & 433 & - & 132 & 433 & 301 \\
\hline 12 & Naringenine-7-o-glucoside & 12.69 & 433 & - & 162 & 433 & 271 \\
\hline 13 & Rhamnetine-o-rutinoside (0.5) & 13.37 & 623 & - & 308 & 623 & 315 \\
\hline 14 & Quercetin (1.6) & 17.83 & 301 & - & - & 301 & $151,121,107$ \\
\hline 15 & Luteolin $(0.2)$ & 17.94 & 285 & - & - & - & - \\
\hline 16 & Naringenin $(0.07)$ & 18.51 & 271 & - & - & 271 & 119,109 \\
\hline
\end{tabular}

\section{Table 2 - Phenolic compounds of the Argan leaves}

\begin{tabular}{llc}
$\mathbf{N}^{\bullet}$ & Compounds (\%) & Retention time (min) \\
\hline 1 & Myricetine 3-Ogalactoside (9,78\%) & 3.4 \\
2 & Myricitrine (54,34\%) & 3.9 \\
3 & Hyperoside (8,69\%) & 5 \\
4 & Quercitrine (21,73\%) & 6 \\
\hline
\end{tabular}

\section{Compounds of tocopherols from Argan oil}

The tocopherols were analyzed by HPLC on a column in the normal phase, directly from vegetable oil without saponification. They were identified by comparison of their chromatogram with controls injected under the same conditions. Their dosage was possible by the use of $\alpha$-tocopherol. The results obtained are grouped in Table 3. Tocopherols are natural antioxidants, they are molecules with carbon chains linked to a quinone function (Bouhadjra, 2011). In vegetable oils there are four groups of tocopherols ( $a, b, g$ and $d$ ). Tocopherols have both a vitamin power (vitamin $E$, in particular a tocopherol) and antioxidant properties (Landrier, 2011). In addition, these compounds can constitute an analytical criterion for controlling the purity of oil. Argan oil is richer in tocopherol (597 to $775 \mathrm{mg} / \mathrm{kg}$ ) than olive oil (50 to $150 \mathrm{mg} / \mathrm{kg}$ ) and also than hazelnut oil (300 to $550 \mathrm{mg} / \mathrm{kg}$ ) (Hilali et al., 2005, 2020). Tocopherols are natural antioxidants, gamma tocopherol has the highest antioxidant power (Bourre and Clement, 1996). Rich in gamma tocopherol, Argan oil is a valuable nutraceutical. Tocopherols (vitamin E) and polyphenols are natural antioxidants. These play an essential role in the prevention of several diseases, because they are anti-free radicals (Carrouf, 2002).

\section{Table 3 - Composition of tocopherols in Argan oil ( $\mathrm{mg} / \mathrm{kg})$.}

\begin{tabular}{lllll} 
Tocopherols & y-tocopherol & o-tocopherol & $\alpha$-tocopherol & $\beta$-tocopherol \\
\hline Argan oil & $631,3 \mathrm{mg} / \mathrm{kg}$ & $59,5 \mathrm{mg} / \mathrm{kg}$ & $26,6 \mathrm{mg} / \mathrm{kg}$ & - \\
\hline
\end{tabular}

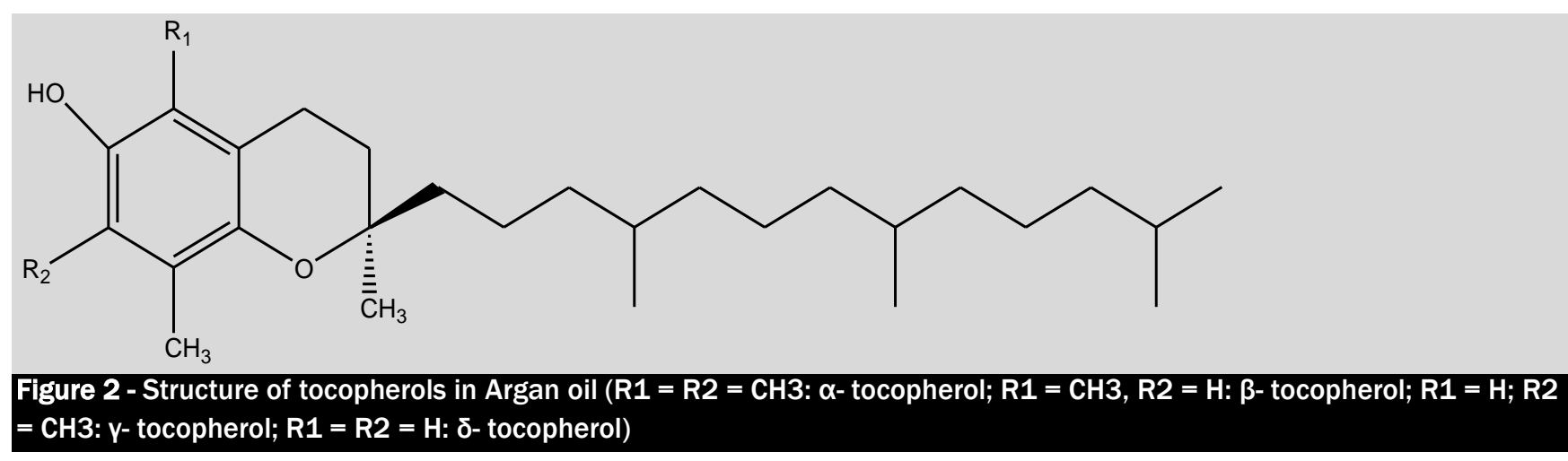




\section{Phenolic compounds of Argan cake}

The cake from the extraction or meal is currently used as feed for fattening cattle. It is rich in carbohydrates and proteins (46.6\% to $49 \%$ ) and contains an important pharmacodynamic group consisting of saponins (Guillaume et al, 2005) and also contains an important group of flavonoids (Table 4). The Argan cake is rich in flavonoids, sixteen flavonoids were found. Among these, epicatechin, catechin, protocatechic acid, vanillic acid and 4-hydroxybenzylic alcohol are higher in Argan cake. On the other hand, epicatechin is a powerful antioxidant from the flavonoid family. A recent American study shows that epicatechin has positive health effects and shows that it can significantly reduce the risks of coronary heart disease and stroke during regular consumption (Rees et al., 2018).

\section{Table 4 - Polyphenols from Argan cake}

\begin{tabular}{llc}
$\mathbf{N}^{\circ}$ & Phenolic compound & Concentration $(\mathrm{mg} / \mathrm{kg})$ \\
\hline 1 & Catechol & 1.4 \\
2 & Resorcinol & 1.3 \\
3 & 4-hydroxybenzyl alcohol & 8.6 \\
4 & Vanillin & 1.1 \\
5 & Tyrosol & 6.2 \\
6 & P-hydroxybenzoic acid & 14.1 \\
7 & (4-hydroxyphenylacetic) acid Alcohol & 1.0 \\
8 & vanillic alcohol & 3.6 \\
9 & 3.4-dihydroxybenzyl alcohol & 0.9 \\
10 & Methyl 3.4-dihydroxybenzoate & 1.6 \\
11 & vanillic acid & 16.3 \\
12 & Hydroxytyrosol & 0.9 \\
13 & Protocatéchic acid & 15.2 \\
14 & Syringic acid & 6.6 \\
15 & Epicatechine & 110.1 \\
16 & Catechin & 11
\end{tabular}

\section{CONCLUSION}

Argan cake is rich in flavonoids. Among these, epicatechin $(110 \mathrm{mg} / \mathrm{kg})$, catechin $(11 \mathrm{mg} / \mathrm{kg})$, protocatechic acid (15.2 $\mathrm{mg} / \mathrm{kg})$, vanillic acid (16.3 mg/kg) and 4-hydroxybenzyl alcohol $(8.6 \mathrm{mg} / \mathrm{kg})$ are higher in Argan cake. Argan oil is richer in tocopherol (597 to $775 \mathrm{mg} / \mathrm{kg}$ ), Argan oil is rich in gamma tocopherol (631 mg/kg), and this metabolite making Argan oil is a valuable nutraceutical. The flavonoid extract of the co-products of the Argan tree has a very interesting anti-radical and antioxidant activity. It is currently marketed as a cosmetic active protector of the skin's extracellular macromolecules such as collagen, glycoproteins for this reason the co-product of Argan has become very important in the cosmetic field and its most widespread marketed.

\section{DECLARATIONS}

Corresponding author: hilali400@yahoo.com

\section{Authors' contribution}

The author reviewed the document and contributed to the development of the content.

\section{Availability of data}

The data can be availed to the journal upon request.

\section{A conflict of Interest}

The author declare that there is no conflict of interests regarding the publication of this paper

\section{Acknowledgments}

The author would like to thank my fellow plant chemistry lab colleagues for their invaluable help and especially Mr. Mohamed Greih. To all the people who contributed directly or indirectly to the realization of this work, I send them my warmest thanks. The author has stated that he is not taking any funding to do this work or to publish this article.

\section{REFERENCES}

Adlouni A (2010). L'huile d'Argan, de la nutrition à la santé. Phytothérapie, 8(2), 89-97. D0I: https://doi.org/10.1007/s10298-010-0538-9

Ba K, Tine E, Destain J, Cissé N, and Thonart P (2010). Étude comparative des composés phénoliques, du pouvoir antioxydant de différentes variétés de sorgho sénégalais et des enzymes amylolytiques de leur malt. Biotechnologie, Agronomie, Société et Environnement, 14(1), 131-139. https://orbi.uliege.be/handle/2268/88077 
Bellefontaine R, Ferradous A, Mokhtari M, Bouiche L, Saibi L, Kenny L, and Meunier Q (2011). Mobilisation ex situ de vieux Arganiers par marcottage aérien. INRA-Maroc (éd.): Actes du 1er Congrès Intl sur l'Arganier, 15-17. http://webagris.inra.org.ma/doc/ouvrages/Arganier2011/Arganier368378.pdf

Bourre JM and Clement M (1996). La vitamine E: comparaison de l'efficacité d'incorporation de l'alpha-tocophérol dans les organes par rapport au gamma-tocophéroL. Bull Acad Nat! Med, 180, 813-829. PDF

Bouhadjra K (2011). Etude de l'effet des antioxydants naturels et de synthèse sur la stabilité oxydative de l'huile d'olive vierge (Doctoral dissertation, UMMTO). https://fshs.ummto.dz/bitstream/handle/ummto/1288/Bouhadjra\%2C\%20Kahina.pdf?sequence=1\&isAllowed=y

Charrouf Z Hilali M, Jauregui O, Soufiaoui M, and Guillaume D (2007). Separation and characterization of phenolic compounds in Argan fruit pulp using liquid chromatography-negative electrospray ionization tandem mass spectroscopy. Food Chemistry, 100(4), 1398-1401. https://doi.org/10.1016/j.foodchem.2005.11.031

Charrouf Z and Guillaume D (2007). Huile d'Argan une production devenue adulte. Les technologies de laboratoire, 2(6). Link I Google Scholar

Charrouf Z, and Pioch D (2009). Valorisation du fruit d'Arganier et Huile d'Argan: Qualité, diversification. Projet Appui à l'amélioration de la situation de l'emploi de la femme rurale et gestion durable de l'Arganeraie dans le sud-ouest du Maroc, Rabat, February. Google Scholar

Charrouf Z (2002). L'huile d'Argane, une prodigieuse vitalité née au bord du désert. Espérance médicale, 9(87), 521-524. https://www.sidiyassine.com/documents/science/article_paru_dans_esperance_medicale.pdf

El Kabouss A, Charrouf Z, Oumzil H, Faid M, Lamnaouer D, Miyata Y, and Miyahara K (2001). Caractérisation des flavonoïdes des feuilles d'Arganier (Argania spinosa (L.) Skeels, Sapotaceae) et étude de leur activité antimicrobienne. Revue Marocaine des Sciences Agronomiques et Vétérinaires, 21(3): 157-162. http://agrimaroc.org/index.php/Actes_IAVH2/article/view/153

Falode JA, Akinmoladun AC, and Olaleye MT (2019). Ameliorative property of Kigelia africana crude and flavonoid leaf extracts on aluminuminduced hepatotoxicity in albino rats. Comparative Clinical Pathology, 28:1495-1506 https://doi.org/10.1007/s00580-019-03004-y

Ghedadba N, Hambaba L, Ayachi A, Aberkane MC, Bousselsela H, and Oueld-Mokhtar SM (2015). Polyphénols totaux, activités antioxydante et antimicrobienne des extraits des feuilles de Marrubium deserti de Noé. Phytothérapie, 13(2): 118-129. https://link.springer.com/article/10.1007/s10298-015-0944-4

Gitton-Ripoll V (2009). Pourquoi il ne faut pas traduire natrum par "Nitre":emplois thérapeutiques de ce minéral dans la médecine humaine et vétérinaire des romaines (Pline, NH 31, 106-117, Scribonius largus, Pelagonius). Bulletin société Histoire de la Médecine et des Sciences Vétérinaires. Bull. Soc. Hist. Méd. Sci. Vét., 9: 5-16. PDF I

Guillaume D, and Charrouf Z (2005). Saponins and secondary metabolites of the Argan tree (Argania spinosa). Cahiers Agricultures, 14(6), 50916. http://revues.cirad.fr/index.php/cahiers-agricultures/article/view/30545

Hilali M, Charrouf Z, Aziz Soulhi AE, Hachimi L, and Guillaume D (2005). Influence of origin and extraction method on Argan oil physico-chemical characteristics and composition. Journal of Agricultural and Food Chemistry, 53(6): 2081-2087. https://pubs.acs.org/doi/abs/10.1021/jf040290t

Hilali M, El Monfalouti H and Kartah BE (2020). Evaluation of the chemical composition of Argan (Argania spinosa L.) oil according to its extraction method, origin of production and altitude. Online Journal of Animal and Feed Research, 10(3): 111-118. Link I DOI: https://dx.doi.org/10.36380/scil.2020.ojafr15

Jiang L, Luo S, Zhou X, Jiang Q, and Deng S (2020). Advances in extraction and purification of litchi polyphenols. Journal of Fruit Science, 37 : 130-139. DOI: https://dx.doi.org/10.13925/j.cnki.gsxb.20190336

Khallouki F, Eddouks M, Mourad A, Breuer A, and Owen RW (2017). Ethnobotanic, ethnopharmacologic aspects and new phytochemical insights into Moroccan Argan Fruits. International Journal of Molecular Sciences, 18: 2277. Doi: https://dx.doi.org/10.3390\%2Fijms18112277

Landrier J F (2011). Vitamine E et physiologie du tissu adipeux. Oléagineux, Corps gras, Lipides, 18(2): 83-87. Direct Link

Morand C and Milenkovic D (2014). Polyphénols et santé vasculaire: mise en évidence du rôle direct des polyphénols dans les effets bénéfiques des agrumes dans la protection vasculaire. Carrefours de I'Innovation Agronomique CIAG: Phytomicronutriments de la plante au consommateur.(42) 2014; Carrefours de I'Innovation Agronomique CIAG: Phytomicronutriments de la plante au consommateur, Avignon, FRA, 2014-12-16-2014-12-16, 11-26. http://agris.fao.org/agris-search/search.do?recordID=LV2016021079

Pumareda L, Henry F, Charrouf Z, Pauly G, and Falconnet G (2006). Valorisation des feuilles d'Arganier: impacto ambiental. Bois and Forêts des Tropiques, 287(287): 35-44. http://revues.cirad.fr/index.php/BFT/article/view/20321

Rees A, Dodd GF and Spencer J (2018). The effects of flavonoids on cardiovascular health: a review of human intervention trials and implications for cerebrovascular function. Nutrients, 10(12): 1852. Doi: https://doi.org/10.3390/nu10121852

Tahrouch S, and Rapior S (1998). L’Arganier: espèce endémique du Maroc. Garance voyageuse, 43, 32-33. Google Scholar

Safer S. (2018). Teneur en polyphénols, tannins et flavonoïdes et capacité antioxydante d'extrait méthanolique d'une plante. Direct Link

Sánchez-Rabaneda F, Jáuregui 0, Casals I, Andrés-Lacueva C, Izquierdo-Pulido M, and Lamuela-Raventós RM (2003). Liquid chromatographic/electrospray ionization tandem mass spectrometric study of the phenolic composition of cocoa (Theobroma cacao). Journal of mass spectrometry, 38(1), 35-42. https://doi.org/10.1002/jms.395

Zhar N, Naamani K, Dihazi A, Jaiti F, and El Keroumi A (2016). Comparative analysis of some biochemical parameters of Argan pulp morphotypes (Argania spinosa (L) Skeels) during maturity and according to the continentality in Essaouira region (Morocco). Physiology and Molecular Biology of Plants : an International Journal of Functional Plant Biology, 22(3) : 361-370. https://doi.org/10.1007/s12298-0160365-z 